\title{
An attempt to set limits on human interference in the environment ${ }^{\star}$
}

\section{Rozpoznawanie granic ingerencji człowieka w środowisko przyrodnicze}

\author{
Michał Latawiec \\ Faculty of Christian Philosophy, Cardinal Stefan Wyszyński University in Warsaw, Poland \\ ORCID: https://orcid.org/0000-0001-8803-4202•m.latawiec@uksw.edu.pl
}

\begin{abstract}
In this article, the author discusses the problem of crossing the boundaries of human intervention in the environment that affect both nature and man. Setting limits on human interference in nature (and in man themselves) is dependent on the type of boundaries. For this reason, the author presents the issues of the role and development of human interference in nature, an attempt to justify the current intervention as well as the associated dilemmas. For the purpose of this analysis, the author formulates a definition of borderline interference in nature. Finally, the author gives examples of exceeding the permissible limits.
\end{abstract}

Keywords: Keywords: environment, human interference, boundaries

\begin{abstract}
Streszczenie: W niniejszym artykule autor omawia problem takiego przekraczania granic ingerencji człowieka w środowisko naturalne, które oddziałuje zarówno na naturę, jak i człowieka. Ustalenie granic ingerencji człowieka w naturę (i w siebie samego) jest zależne od rodzaju tych granic. Z tego względu autor prezentuje kwestie roli i wzrostu ingerencji człowieka w naturę, próbę usprawiedliwienia współczesnych ingerencji i związane z tym dylematy. Dla potrzeb tej analizy zostaje zdefiniowana linia graniczna ingerencji w naturę. W części końcowej wskazane są przykłady rozszerzania dopuszczalnych ograniczeń.
\end{abstract}

Słowa kluczowe: środowisko, ingerencja człowieka, granica

\section{Introduction}

The problem of crossing the boundaries of human interference in the natural environment has accompanied us since almost the beginning of our existence. However, it can be noticed that the severity of the problem has occurred at the turn of the 19th and early 20th century. This is the moment when the degradation of the natural environment was recognised and it was understood that many of the initiated processes are irreversible. The discussed topic is important because human interference is massive, perhaps even non-reflective. Moreover, the effect of the changes in the environment is immediately noticeable on the scale of the evolutionary processes - and nature has no time to adapt to them.
The changes affect, almost immediately, entire ecosystems or individual species of biodiversity. Examples include acid rain or climate variations, which are negatively influenced by a man. While we originally interfered with nature to make our life easier by subordinating the environment to a man, now, increasingly, interventions are aimed at overcoming the negative effects of

"This article was originally published in Polish as Latawiec, Michał. 2016. "Rozpoznawanie granic ingerencji człowieka w środowisko przyrodnicze." Studia Ecologiae et Bioethicae 14(1): 77-97. The translation of the article into English was financed by the Ministry of Science and Higher Education of the Republic of Poland as part of the activities promoting science - Decision No. 676/P-DUN/2019 of 2 April 2019. Translation made by GROY Translations. 
human activity and the dangers associated with it. We are taking legal, economic and social measures to stop environmental degradation and minimise the negative effects.

A man and the environment are one interconnected whole, and any interference has an impact on this unity. This raises a question of the effects of the interference, which can only be seen immediately or only after some time. A man needs to know the relationship between their actions and effects - they need to enter the cause-effect dependencies. Thus, setting the boundaries of human interference in nature (and in themselves) depends on the type of those boundaries. It is worth to remember the words of John Paul II, spoken in Toruń: "Scholarship today, including Polish scholarship, faces great challenges. The unprecedented development of the sciences and technological progress are raising fundamental questions about the limits of experimentation, the meaning and direction of technological development, the limits of man's tampering with nature and the natural environment. This progress gives rise to both wonderment and fear. Man is becoming ever more fearful of the products of his own intelligence and freedom. He feels endangered" (John Paul II 199, no 6). Therefore, the situations in which such human interference in nature occurs should be looked at and the validity of such interference should be examined.

\section{The role of the interference}

The nature of human interference depends on the links between a man and nature. Therefore, it should be pointed out that "the realistic description of the place and the role of man in the biosphere requires a recognition of the fact that both a man and nature are autonomous but interrelated beings. This interdependence manifests itself in the fact that nature shapes a man. A man can shape it according to their ideas and planned designs" (Hołaczek, i Lubański 1988, 17).

A contact of a man with nature happens in two ways. Firstly, a man is part of nature thanks to their physicality. Secondly, the same physicality prompts a man to constantly need nature. And as Ślipko points out, there is also a certain disparity in the relationship between a man and nature. "Nature is independent of a man in its existence: it existed for a long time when there was no man, and it could have continued to exist in the same way, even if a man did not appear in it. It is the nature's "strong side" that turns out to be her weakness: it contains many resources that make her able to meet the needs of a man. So a man "can" and "has to" make use of nature. We know, based on our experience, how great the "needs" of a man are, and also that the possibilities of satisfying them by nature are equally high" (Ślipko 1999, 134).

The asymmetry between a man and nature is also emphasised by Broniewski (1995, 61-79). He correctly notices that nature can survive without a man, and a man depends on nature to survive. However, it can be assumed that there are still too many people who do not want to acknowledge this act.

It is important to remember that the area of a discussed interference is both nature and a man. A man can correct mistakes of nature, for example by performing surgeries to separate Siamese twins. They should not, however, improve nature by altering women figures through plastic surgeries which are only a reflection of temporary fashion. It is different in case of reconstruction plastic surgeries, for example after a mastectomy, which not only improves the appearance but is designed to protect mental health. Thus, the conservation area will include both nature and a man.

An interference with nature can be justified by four main types of needs of man. The first one, the most important one, are primary or basic needs for human existence. Those include ensuring access to water, food, shelter etc. The second one are economic and social needs. Those interventions, in addition to the development of societies, also relate to the removal of the effects of an ill-advised human economy. We are therefore talking about an interference aimed at solving past problems. Then, there are the socio-cultural needs. Here, we are talking about the inter- 
ference related to making the natural world available. On the one hand, this concerns an interference that is intended to help to reach places that are hard to reach in normal conditions, while on the other, it can involve deliberate limitations of access. The last group of needs result from nature protection and are a special form of interference - interference for a man and against a man.

The indicated needs for the interference in nature somewhat reflect the order of our activities. An approach can be noticed that the need to protect nature is only taken into account as last. Besides, individual interferences resulting from human needs can vary in scale as well as in strength. It is our attitude towards the natural world and towards a man that is responsible for that.

The situation is a bit different while discussing the goals of the interference. They can be ad hoc to get a quick effect. A classic example here is the use of Lake Victoria, where, deliberately, an alien species of fish was placed, the Nile perch (Lates niloticus). The socioeconomic aspects were decisive while making this decision. And although fishery has improved in the early years, the ecological consequences became apparent over time (Pringle 2005). The introduced predator, by winning the food fight, eliminated about two hundred species of rare animals from the ecosystem of the lake and caused a decline in the number of many others. The negative effects of the Nile perch on Haplochromini cichlids have resulted in algae growth, water cloudiness, and the expansion of anaerobic areas in the waters of Lake Victoria (Goldschmidt et al. 1993). It is worth noting that the Nile perch is now considered one of the 100 most dangerous invasive alien species (ISSG 2015).

The objectives of the interference may also be dictated by ideological or philosophical reasons. Therefore, when talking about food modification, for example, such interventions are most often aimed at eliminating hunger or reducing food waste during transport. Even so, it can be seen that the problem of world hunger is still not resolved. According to the Food and Agriculture Organiza- tion, between 2010 and 2012, around 870 million people, that is one in eight people, suffered from hunger (FAO 2013).

\section{Development of interference}

Crossing the boundaries by a man has already been noticed a long time ago. "A man has changed the face of the globe to such an extent that they destroyed the harmony of the environment in which they were created Instead of landscapes in balance with our needs, we have created hideous, disgusting and utterly perverse places" (Dorst 1971, 18).

Emberger stated that the natural order has been disrupted and is often transformed. "In one word, a man, through their uncooperative intelligence, became a forger of nature and a factor of disorder" (Emberger 1960, 32). A man, living in a particular environment, imposes changes on their environment. Over time, people have separated themselves from their original nature. By transforming the world consciously and unconsciously, they have created artificial nature - an anthropogenic environment. Such an environment not only separates a man from nature but can also cause threats to both nature and man themselves. The approach, which is counter to the rational management of nature, has contributed to the negative impact on nature. However, one can see, that the easier and more frequently we cross the boundaries, the further away we are from nature.

The mechanism of ill-thought-out interference is described by Engels in Dialectics of Nature: "But let's not flatter ourselves too much because of our human victories over nature. For every one of them, it takes revenge on us. Each victory gives us results we were hoping for in the first place, but in the second and third it brings different, unforeseen consequences, which often distort the meaning of the first ones" (Engels 1953, 183).

This view was illustrated by an example of the hasty grubbing up of forests for the cultivation of land, which leads to elimination of water storage sites and conversion of those areas into deserts. The second example is the deforestation of ridges of the 
mountains, which consequently destroyed the traditional grazing of sheep, and during the driving rain, it became the cause of violent flood surges.

Thanks to the progress in science, we can predict the effects of our interference with nature. A better understanding of the interrelationships that occur in the natural world imposes new responsibilities on people and increases responsibility for their actions. Demographic problems and the state of the environment do not allow to leave the exploited areas for nature to regenerate. We need to make use of our technical achievement. "Despite the considerable development of science and a better understanding of the laws of nature, [this situation] makes a man even more dependent on nature, since once its balance is strongly disturbed it cannot always be restored to normal even with currently available technical resources" (Zabierowski 1978, 26).

It is worth recalling here, that we can now distinguish three dominant attitudes towards nature, arising from the development of science and technology. The first one concerns scientists who preach boundless confidence in the progress of civilisation, identified with a belief in the ability to solve all economic and social problems through the development of civilisation. The second group are representatives of a catastrophic or a technophobic point of view. They see many threats in technical development, among others, lifestyle diseases affecting a man. The last group are supporters of the moderate (Aristotelian) position, who are convinced that the maximum harmony with nature must be maintained while avoiding harmful elements of technology (Jaron 1998, 84). It seems that the greatest influence on the development of intrusion into the environment, have people who are convinced of the limitless possibilities of technology. "Based on that, many contemporaries believe that we have the right to burn down any bridges connecting us to the past. All connections that have been created so far between a man and nature seem to them out of date. The eter- nal alliance between a man and nature has been broken, as it seems for a man to have become capable of freeing themselves from the biological dependence on it since their appearance on the Earth" (Dorst 1971, 15). Only the second group consist of those unaware of their environmental impact.

\section{Justifications and dilemmas of present interference}

The natural justification for interfering into the environment can be presented in four points. The first one stems from a desire to protect rare endangered species. This threat can be a consequence of human activity as well as natural processes, and the threat itself can be real and current, but also potential. We are therefore conducting acts of protection, starting with restitution and ending with reintroduction. The second one is a desire to preserve entire ecosystems, including many valuable natural habitats. The next one concerns the protection of the properties of the environment, including beauty, uniqueness and biodiversity. The last one is the result of a desire to protect a man from a man and for man.

An example of justified interference may be a reconstruction of the fir-beech woodland at the site of the spruce monoculture $^{1}$. In this case, an action must be taken to stop the disastrous consequences of wrongly made decisions. Further interference will therefore be an attempt to repair the habitat. As a result, we protect species, care about the quality of habitats, we protect landscape and biodiversity.

The points indicated above are sometimes difficult to implement. In case of protecting endangered species, our interference is limited. In the case of African elephants, conservation efforts focus on helping in situations which result from human activity. Therefore, for instance, we help animals that have fallen into wells dug by a man and cannot get out of them. We do not try to help animals when their current condition is a result of natural processes (Fishlock

\footnotetext{
${ }^{1}$ For the consequences of the introduction of monocultural woodlands see (Jarosz 1957, 80-88).
} 
2014). Thus, we do not treat the wounds of animals inflicted by other individuals. Similarly, we do not deter natural predators so as not to disrupt natural processes. Excessive interference to protect one kind of species can lead to the loss of another.

Thus we come to dilemmas that are difficult to resolve. One of them is the issue of the permissible level of interference to protect nature, and therefore the scale and circumstances in which we conduct our operations It is clear that we should eliminate our negative impact on the environment and its effects. The question arises: What about the situation when time passes since our interference and a completely different, new and, at the same time, a valuable element of the environment is developed? A good example is the Błędowska Desert. The area was originally covered with forests and dense vegetation. From the 13th century, mining of lead ore, zinc and silver began in the area of Olkusz. Additionally, until the middle of the18th century, logging was carried out and the wood was used to support the shafts of mines and tunnels, and to operate metallurgical furnaces. Consequently, a habitat devoid of all vegetation was created. In the middle of the 20th century, the exploration of sand from the area began and foreign species of trees were planted in parts of it, including red oak (Quercus rubra) and sharp-leaf willow (Salix acutifolia). This caused another gradual change of the character of this place. Presently, the undeveloped part of the area "is a geological uniqueness of nature on a continental scale. Until recently [the desert] was only Europe's largest inland area of loose sands" (Bryś i Gołuch 2011, 5). In 2007, Błędowska Desert has been protected as an area of community importance, PLH120014 Pustynia Błędowska, where work is being carried out to prevent natural succession. The above description shows that the present appearance of the desert is the result of significant degradation of the entire area. Nowadays, however, we want to protect the developed habitat and our interventions are aimed at preventing the resto- ration of the condition before our initial, significantly negative interference.

Another dilemma concerns environmental interference resulting from a desire to save valuable elements of nature threatened by natural processes. One of the examples is Isle Royale National Park, which covers an area of a group of islands in the state of Michigan (USA). Due to its location, it is virtually isolated from direct human interference. Scientific research is carried out there on a predator-prey relationship, in this case, a wolf (Canis lupus) and moose (Alces alces). The closed environment has led to an increase in the phenomenon of inbreeding of the wolf population (Hedrick 2014). This raises the question of the right of interference and an introduction of individuals from outside, with new genetic material, to improve the condition of wolves in the wild. As a result, we will disrupt natural processes in an isolated environment, but at the same time, we will probably save the wolf population. The dilemma is even greater because the wolves, as well as the moose, got to the island via natural ice bridges that form periodically. Those, in turn, are created less and less frequent, due to the change of the climate.

Similar issues can be noticed with reference to plants. Rare whitebark pine (Pinus albicaulis) grow in the northern part of the United States. They are considered threatened species by the IUCN. Those trees are currently threatened by white pine blister rust- a disease caused by rust fungus Cronartium ribicola (Zaffos 2014). It is worth remembering that this pine is keystone species. This means that it is a type of species that determines the stability of biocenosis, that is, has a large influence on the trophic network system. Removing it from the trophic network can result in large and irreversible changes throughout the whole biocoenosis.

Examples of the interference that we justify include the need to eliminate alien species from particular ecosystems. However, it is important to remember that invasive alien species in their native habitats may require protection. 
Another issue is the justification of environmental interference arising from a simple desire to help in the name of conservation. Often, because of the desire to establish a closer relationship with nature, we unconsciously cross certain boundaries. This action aims at increasing our sense of connection with nature. This can be described as a response to distancing from nature. However, the consequences of such actions usually have a negative impact on the environment.

Human interference in naturally valuable areas can arouse mixed feelings. It seems that the simplest way to set a boundary of interference would be to ban all human activity in a given area and leave such a place solely to natural laws, however, this solution may be unreliable. Firstly, it is difficult to find places on the Earth where a man would not leave their mark. Over the millennia of our activity in the world, we have developed many semi-natural ecosystems that we are protecting today. In those areas, many elements have developed, which are valuable today and would disappear without further human interference. Secondly, such areas although created to be protected from a man - are made available to people for two main reasons: research and tourism. Thanks to this, nature has a beneficial effect on human development, both externally (physically) and internally (psychologically emotionally and spiritually). At this point, it can be assumed that the influence of nature on a man is generally beneficial, whereas the influence of a man on nature usually is not.

\section{Definition of a border and a borderline}

In this article, one should pause for a moment on the concept of a border. According to a definition in the dictionary of the Polish language, a boundary is a point or a line that cannot be crossed; set by a man; it divides and restricts, sometimes gives a sense of security. Therefore borders are not only set to divide and limit but also - more importantly - to ensure security and protection. Nevertheless, setting boundaries often leads to conflicts, or at least many misunderstandings, between social groups representing different interests and pursuing opposite values or priorities. An additional problem is identifying a border with a limitation. In the case of conservation of nature, we often talk about restricting rights, such as property. Less than a century ago, Jan Gwalbert Pawlikowski, among others, wrote about problems resulting from poorly understood laws (Pawlikowski 1938, 3-53).

Let us attempt to present the characteristics of boundaries. First of all, it is important to keep in mind that they can be variable. Boundaries are set by a man, not by nature. And so they are broken by a man themselves. It is worth to remind, that often a measure of progress of civilisation is pushing the boundaries. Such an ability to cross boundaries is often the hope the man aspires to. On the other hand, boundaries are set by a man for their own safety.

The boundaries are blurred, so we have difficulties in setting and respecting them. Speculations concerning boundaries also relate to the role and place of a man in the environment. Presently, the image of a man in the environment - just like the previous ones - is shaped by social, economic and political changes. In the transformations of various systems that occur here, a man acts on behalf of nature. Therefore, disputes occur between man and man, and not between man and nature. People who are used to living without responsibilities and consequences find it difficult to change their lifestyles and take responsibility for their actions. However, we can notice changes with the advent as Kozłowski (1993) has described it - of the ecological era. Attempts to change our attitude to the environment are supported by various ideas, such as sustainable development, eco-ethics and eco-philosophy.

Attempts to set boundaries on the interference of a man in the environment usually appear in the context of protected areas. Since we cannot fully eliminate the presence of a man in the protected areas, other methods of setting boundaries are chosen. Based on ecological knowledge, we take into account, for example, the tolerance ranges of individual organisms. "In practice, the 
relationship between life and the environment has many complications, arising, for instance, from the fact that the same organism may a have a different level of (varying widely) tolerance to different environmental factors, that the tolerance of an organism may change very substantially during its growth and individual development, that a response of an organism or an ecosystem may be gradual (proportional to the intensity of the changes) or zero («everything or nothing») - a delayed bomb mechanism. Therefore, the key to a discussion about the limits of interference that interest us here is reliable knowledge of the limits of tolerance of organisms and their relationship with the environment" (Mirek 2010, 14).

It is worth paying attention to the proposal of Pociask-Karteczka, who calls for an adoption of a two-stage procedure of setting boundaries of human integration into the natural environment (although it concerns protected areas, it can be applied to the whole environment). The first stage is to identify the mechanisms of functioning of the environment at the level of physical relationships between individual elements (including humans), both internal and external. The second stage is to identify the consequences of the interference in a wider social perspective, which is done in a process of analysing the losses and gains of individual social groups. "While the initial stage aims at diagnosing the actual state of the environment and the description of the state of a target - it is usually easy and does not create difficulties considering the current level of science and research methods - the social aspect of the discussion is the most difficult and problematic one" (Pociask-Karteczka 2010, 17).

It is not possible to set a precise boundary of permissible interference, as this limit will vary depending on the area of undertaken interference. However, this area can be gradually expanded, starting from a man, through the anthropological (social, cultural) environment, and ending with the world of wild nature.

Thus, relating to those issues, we can talk about a borderline. The concept of a bor- derline was introduced in philosophy by Szczepan Ślaga. However, it should be remembered that the term was used in the context of defining an area between animate and inanimate matter ${ }^{2}$. The author stated that it is "a kind of a bridge where matter meets the living world in its minimally, barely discernible, manifestations" (Heller et al. 1992, 300). For this analysis, we understand this concept as a fuzzy area that includes activities that are legally or ethically unregulated, often resulting from disturbed consciousness. Since the boundaries are blurry, it is impossible to set sharp boundaries This also applies to the physical aspects of a boundary. Even in the case of protected areas, we create a buffer zone that is a zone which is supposed to be a buffer between protected nature and direct human influence on it. However, it is indisputable that we must strive to identify the borderlines of our interference.

An expression of a borderline may be anthropogenic nature, which is characterised by a status difficult to determine. It was formed between others because of our culture, and thus is the result of our interferences over many centuries Thus, it will be semi-natural ecosystems and a whole set of synanthropic species that accompany a man. A borderline arises from several reasons, including a lack of knowledge of the consequences of interference; a lack of knowledge of the limits of tolerance of nature; resulting from the variability of the tolerance of nature, from the different range of tolerance of nature; imbalance and

\footnotetext{
${ }^{2}$ This idea is developed by A. Latawiec, claiming that "nature consists of both inanimate and animate matter. For an average man, the line between those two types of beings is clear: either something is alive or dead. Meanwhile, the problem is more complex. First of all, we are not clear regarding the unequivocal indication of the features of living creatures, and consequently also of the features of inanimate beings. There is also a lack of sufficient criterion to make it clear whether or not an object from the natural world is alive. There are many similarities in the structure and properties of living and dead matter, and in the study of their microstructure, the differences between them become increasingly blurred. It seems that neither scientists (naturalists) nor philosophers can clearly identify those differences" (Bugajak et al. 2009, 188).
} 
disorder of order in nature. Therefore, a man must get to know and understand nature. A boundary should be a zone between protected and unprotected, between desirable and undesirable effects, between beneficial and unfavourable changes.

\section{Crossing boundaries}

There are many examples of adverse environmental interference. One of them is undertaking irrational forest management, where the consequences become apparent over time. "Any mistakes made in forest management are more dangerous than in other areas because forestry deals with long production periods. Most of the time, what we plant now will be used by our children, or even by our grandchildren and great-grandchildren, therefore it is urgent to restore forests to their near-natural character" (Leńkowa 1961, 33).

This is dangerous as the relatively long period during which the adverse changes occur can make it difficult to notice the adverse changes. Our vigilance is thus put to sleep, and the deteriorating conditions are considered a natural state.

Crossing the boundary will also be incompetent helping animals, which is the result of a disturbed ecological awareness. Sometimes the desire to protect small animals, for example, against meat-eating predators will involve meddling in the food chain. While we support small animals in this case, we are undeniably unfavourably interfering in the world of predators. Such actions are probably contrary to natural processes and limitations of food for many animals, and consequently, we make many species completely dependent on a man. This can lead to a situation where certain species will function only as long as a man takes protective actions. In such situations, we must artificially maintain the created natural balance.

The problem of animal dependence on a man is easily illustrated by an example of feeding them, especially in cities. It is a common form of networking and communing with a substitute of wild nature It is also a way of building a pro-environment attitude, mostly among children. Feeding animals, mainly birds, is a common sight. On the one hand, it is a sign of caring for animals or caring for the environment expressed by sharing food, but in general, careless and carefree feeding of animals adversely affects those animals, which often change their behaviour. in the case for birds, it is most common for them to stop migrating and stay where a man provides them with food. As a consequence, animals, initially having sufficient food, get used to the new place and do not undertake further migration The situation is complicated during cold and snowy winters when most of the people who feed them do not do it so regularly or even stop their activity. This restriction of food at the most difficult time for animals is disastrous. Furthermore, regardless of the species, the distance between an animal and a man is dangerously shortened as a result of feeding.

The consequence of taming animals, for example, by tourists is not only shortening the distance but also attracting animals to human habitats. Unfortunately, as shown by numerous examples from the Tatra Mountains region, bears are the only ones who suffer the consequences for the irresponsible behaviour of tourists, because the animals that show excessive trust and are not afraid of a man are taken to zoos or killed (Borucki 2005).

Similar problems arise from a desire to help. It often happens in spring, when we see a lone chick, we automatically want to "save" them by taking them home or to a vet. However, the chick is, within some distance, guarded by one of the parents. Even if the abandoned individual becomes food for other animals, it is still a natural process occurring in nature. Without knowing the behaviour of animals, we often misinterpret their behaviour. By interfering with the natural world, we influence changes in the environment. Although they are an expression of our interest in nature and our desire to help it, they are harmful. It seems, that we should be helpful to nature in order to correct our mistakes, so we should primarily help animals 
that have suffered as a result of our interference, for example, mammals that are victims of traffic accidents, or birds that broke their wings after hitting bridge structures or crashing against the glass walls of buildings. A classic example of crossing a boundary is the continual introduction of species into new habitats. Those species, often with lower environmental requirements, become dangerous rivals for native species in a new location. Unfortunately, in most cases, the scale and extent of the threats those species cause are discovered too late. It is enough to recall here the experiments of introductions made on the Australian continent. It is worth noting here, that the biggest damage was caused by the species accompanying a man such as cats and mice.

Based on the above examples, it can be seen that any unwelcome interference is a bad violation of the borderline. Those interventions can be direct when the effects are immediate, or indirect - distant in time and space. Setting the boundaries of interference of a man in nature - and within themselves - depends on the type of those boundaries. That is, talking about direct boundaries, we can create a directory of dos and don'ts regarding our activity in the natural world. Legislation and conservation plans may also be a tool here, however, the utmost care must be taken to ensure their effectiveness. In the case of potential boundaries, it is not possible to define a universal catalogue of limits of interference, however, a man can aim to develop proper ecological awareness, to determine the directions of human activity based on responsibility, cautiousness, prudence, among other things. In this case, we are trying to regulate boundaries with ethical aspects.

It is worth remembering that the sources of many intrusions, which cross the boundaries, lie at the root of a separation of a man from nature. Similarly, intrusions can be considered by their goal (conscious - unconscious) and effect (favourable unfavourable). However, recognising the need to set a boundary against evil interference is an expression of a desire to pro- tect both nature and man. We often cross the boundaries as a result of our multiculturalism and different traditions that justify our actions. At the same time, it makes it impossible to create a universal catalogue of permissible interference.

\section{Conclusions}

It should be remembered that a man and the environment constitute one, interrelated whole, and every interference has an impact on this whole. The issue of crossing the boundaries of interference of a man in the environmental concerns those actions that affect both nature and a man. The nature and purpose of those behaviours have changed in the past. Originally, we interfered with nature to facilitate our existence by subordinating nature to ourselves, but nowadays, to a large extent, the interference is aimed at overcoming the dangerous effects of human activity. Besides, the effects of interference might not be immediately visible, but only become apparent after some time.

This is done on several levels in order to stop environmental degradation and minimise the negative effects of activities of a man. It is often justified by the necessity to make difficult choices. The limits of interference on a man in nature concern both physical aspects and the relationship between a man and the world around them. Setting precise boundaries for human interference in nature (and in themselves) is impossible, even though it depends on the type of crossed boundaries. I propose, for this reason, to speak of a borderline of such interference.

\section{Bibliography}

Borucki, Tomasz. 2005. Niedźwiedzia przystuga. Dostęp 05.10.2015. http://pracownia.org. $\mathrm{pl} /$ dzikie-zycie-numery-archiwalne,2136,article,2703.

Broniewski, Witold. 1995. „Człowiek a przyroda." Człowiek i przyroda 2: 61-79.

Bryś, Henryk, i Piotr Gołuch. 2011. „Pustynia Błędowska dawniej i dziś - interpretacja wieloczasowych zdjęć lotniczych i obrazów satelitarnych." Acta Scientiarum Polonorum Geodesia et Descriptio Terrarum 2: 5-16. 
Bugajak, Grzegorz, Jarosław Kukowski, Anna Latawiec, Anna Lemańska, Danuta Ługowska, i Adam Świeżyński. 2009. Tajemnice natury. Zarys filozofii przyrody. Warszawa: Wydawnictwo UKSW.

Dorst, Jean. 1971. Zanim zginie przyroda. Warszawa: Wiedza Powszechna.

Emberger, Louis. 1960. «Les relations Homme-Nature." Actes de la Société Helvétique des Sciences Naturelles. Partie scientifique et administrative 140: 31-43.

Engels, Fryderyk. 1953. „Rola pracy w procesie uczłowieczenia małpy." W Dialektyka przyro$d y$, red. Fryderyk Engels, 172-187. Warszawa: Książka i Wiedza.

FAO. 2013. FAO Statistical Yearbook 2013. Rome: World Food and Agriculture.

Fishlock, Victoria. 2014. Keeping elephants wild: choosing not to intervene in the natural cycle of life. Accessed October 5, 2015. http:// www.ifaw.org/united--states/news/keeping-elephants-wild-choosing-not-intervene--natural-cycle-life.

Goldschmidt, Tijs, Frans Witte, and Jan Wanink. 1993. "Cascading Effects of the Introduced Nile Perch on the Detritivorous/Phytoplanktivorous Species in the Sublittoral Areas of Lake Victoria." Conservation Biology 7(3): 686-700.

Hałaczek, Bernard, i Mieczysław Lubański. 1988. „Filozoficzne aspekty ekologii.” Chrześcijanin a Wspótczesność 5: 43.

Hedrick, Philip W., Rolf O. Peterson, Leah M. Vucetich, Jennifer Rae Adams, and John Andrew Vucetich. 2014. "Genetic rescue in Isle Royale wolves: genetic analysis and the collapse of the population." Conservation Genetics 15(5): 1111-1121.

Heller, Michał, Mieczysław Lubański, i Szczepan Ślaga. 1992. Zagadnienia Filozoficzne Wspótczesnej Nauki. Wstęp do filozofii przyrody, Warszawa: Wydawnictwo ATK.

ISSG (Invasive Species Specialist Group). "The Global Invasive Species Database." Accessed October 5, 2015. http://www.issg.org/ database/species/ecology.asp?si=89.

John Paul II. 1999. "Address at Meeting with Rectors of Academic Institutions." (Nicolaus Copernicus University in Torun, 7 June 1999). Accessed October 29, 2020. http://www.vatican.va/ content/john-paul-ii/en/speeches/1999/june/ documents/hf_jp-ii_spe_19990607_torun.html.
Jaroń, Józef. 1998. „Typologia ekofilozofów i postaw Homo sapiens wobec przyrody." W Humanistyka, przyrodoznawstwo, technika $w o b$ liczu kryzysu biosfery, red. Jan Dębowski, 7785. Olsztyn: Wyższa Szkoła Pedagogiczna.

Jarosz, Stefan. 1957. „Ochrona zasobów leśnych w Karpatach." W Ochrona Zasobów przyrody podstawa gospodarki narodowej. Referaty $i$ uchwaty zwyczajnej sesji Państwowej Rady ochrony Przyrody odbytej $w$ Warszawie w dniach 15 i 16 XI 1956 r., red. Państwowa Rada Ochrony Przyrody, 80-88. Warszawa: Liga Ochrony Przyrody.

Kozłowski, Stefan. 1993. Rio. Szczyt Ziemi. Poczatek ery ekologicznej. Łódź: Akapit Press.

Leńkowa, Antonina. 1961. Oskalpowana Ziemia. Kraków: Polska Akademia Nauk.

Mirek, Zbigniew. 2010. „Granice ingerencji człowieka w przyrodę obszarów chronionych." Pradnik. Prace i Materiaty Muzeum im. Prof. Wtadystawa Szafera 20: 11-20.

Pawlikowski, Jan G. 1938. „Kultura a natura.” W O lice Ziemi. Wybór pism, red. Jan G. Pawlikowski, 3-53. Warszawa: Państwowa Rada Ochrony Przyrody.

Pociask-Karteczka, Joanna. 2010. „Czy istnieją granice ingerencji człowieka w środowisko przyrodnicze?" W Nauka a zarzadzanie obszarem Tatr i ich otoczeniem. Człowiek $i$ środowisko, red. Zbigniew Krzan, 11-19. Zakopane: TPN.

Pringle, Robert M. 2005. "The Origins of the Nile Perch in Lake Victoria." BioScience 55: 780-787. Stownik języka polskiego. 2013. Warszawa: PWN. Ślipko, Tadeusz. 1999. „Ekologiczna doktryna kościoła." W Rozdroża ekologii, red. Tadeusz Ślipko, i Andrzej Zwoliński, 9-181. Kraków: WAM.

Zabierowski, Kazimierz. 1978. „Ekonomiczne uwarunkowania w ochronie przyrody." W Ochrona i ksztattowanie środowiska przyrodniczego, red. Włodzimierz Michajłow, i Kazimierz Zabierowski, 21-50. Warszawa-Kraków: PWN.

Zaffos, Joshua. 2014. A New Challenge for Wilderness: To Intervene or Not to Intervene? Accessed October 5, 2015. http://www.earthisland. org/journal/index.php/elist/eListRead/a_new_ challenge_for_wil-derness_intervene_or_not/. 